\title{
Belgeo
}

Revue belge de géographie

$1-2 \mid 2012$

Inaugural issue

\section{Geographical Journals in Spain : from Tradition to Fragmentation}

Les revues géographiques en Espagne: de la tradition à la fragmentation

\section{Aurora Garcia Ballesteros and Carles Carreras I Verdaguer}

\section{(2) OpenEdition}

\section{Journals}

\section{Electronic version}

URL: http://journals.openedition.org/belgeo/6016

DOI: $10.4000 /$ belgeo.6016

ISSN: 2294-9135

\section{Publisher:}

National Committee of Geography of Belgium, Société Royale Belge de Géographie

\section{Electronic reference}

Aurora Garcia Ballesteros and Carles Carreras I Verdaguer, « Geographical Journals in Spain : from Tradition to Fragmentation », Belgeo [Online], 1-2 | 2012, Online since 15 December 2012, connection on 30 April 2019. URL : http://journals.openedition.org/belgeo/6016; DOI : 10.4000/belgeo.6016

This text was automatically generated on 30 April 2019

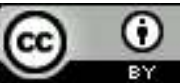

Belgeo est mis à disposition selon les termes de la licence Creative Commons Attribution 4.0 International. 


\section{Geographical Journals in Spain : from Tradition to Fragmentation}

Les revues géographiques en Espagne: de la tradition à la fragmentation

Aurora Garcia Ballesteros and Carles Carreras I Verdaguer

1 This article reviews the short and diversified history of the Spanish Geographical journals, within the framework of the general Spanish geographic tradition (Bosque et al., $1984,1987,1990,1992,2004)$. During the second half of the $20^{\text {th }}$ Century, a fragmentation of the university Geography groups took place with a multiplication of journals. This fragmentation appears as a big difficulty to reinforce and internationally disseminate the main results of Spanish geographical research. Through the most popular journals database it is possible to evaluate the impact of these Spanish journals, which is always very low. Some conclusions related to language and content problems are advanced in order to improve the knowledge of the great and diversified Spanish geography all around the world.

\section{The beginnings}

2 The publishing of scientific geographical journals in Spain has experienced deep quantitative and qualitative changes since mid-20 ${ }^{\text {th }}$ century. Up to 1950 there were only two journals. The oldest is the Boletín de la Real Sociedad Geográfica, published yearly in Madrid since 1876 by the institution of that name, the oldest of the Spanish geographic associations, founded on that year under the name Sociedad Geográfica de Madrid, after the example set by other countries and within the time's currents and ideas that analyzed contacts between nations, colonial expansion, discoveries and what was then thought as Geography as a priority object for the State.

In the Boletin they published till very recently more of such topics than real academic geographic research works.

In 1940, the Instituto Juan Sebastián Elcano, of the Consejo Superior de Investigaciones Científicas (Higher Council for Scientific Research) (CSIC), started publishing the journal 
Estudios Geográficos, once every three months until 2004 and every six-months since 2005. Its object, highlighted in the first issue, was to make scientific research in the wide field of Geography; thus until 1954 it was the only journal that published articles, specially regional monographs, next to the most representative scientific research of Spanish Geography (whether of a conceptual and methodological character, or of spatial and territory analysis), and to articles related to other similar sciences, such as Cartography, Geology, Ecology, Forestry, Edafology, Economy, Demography or Sociology. There was also a section on News and Comments that made reference to researches in progress or to other related subjects, and a section on Book Reviews that gave account of those books that, in the opinion of the publishers, were most important among those published in Spain and in other geographic schools, the French and even the German in the first years, and later on the English one. It was and still is, undoubtedly, the most widespread Spanish journal, and it is present in the libraries of almost every Spanish and foreign universities with Geography department.

In 1954 the just-created (1952) Department of Applied Geography of the Universidad de Zaragoza started publishing Geographica, whose contents was related to geographical information and teaching as well as to research techniques and teaching materials, in order to be a supplement to Estudios Geográficos. In 1958 the CSIC's Instituto de Geografía Aplicada in Madrid began to publish it. In 1986 the publisher decided to reduce the number of journals it was publishing, and they kept Estudios Geográficos as their only Geographical journal.

6 Apart from these three clearly geographical journals, we can add also Pirineos, published since 1945 by the Instituto de Estudios Pirenaicos, also included in the CSIC, and specialized in Physical Geography topics.

\section{The launching}

7 Geography increased its presence in the university in the 1960s and 1970s which was linked to the publishing of new geographical journals, most of which are still published with a higher or lower dissemination and impact at present. Thus, in 1964, Cuadernos de Geografía was born in the Universidad de Valencia ; its main object was to publish original and non-published research articles related to the Valencian territory or to a wider spatial area, as well as theoretical and methodological papers.

In 1967, the Revista de Geografía was started by the Universidad de Barcelona, releasing it once a year. Its contents was to be a wide and diverse range of Physical, Human and Regional Geography questions and problems, from methods and techniques to the presentation and reflection on history of Geography and Geographical Thought. It kept its continuity until 1997, then after a double issue that covered years 1998-1999, it started a new stage in 2002 as the journal of the Geography Departments of the Universities of Barcelona, Lleida and Tarragona.

The 1960s ended in 1968 with the publishing of Papeles de Geografía in the Universidad de Murcia. This journal underwent several ups and downs and it is still published once every six months at present. In 1970, Trabajos de Geografía was published in the Universidad de las Islas Baleares, although its Humanities School was dependent then on the Universidad de Barcelona. The journal did not have a clear publishing periodicity and it published basically monographs related to the Balearic Islands. Its publishing was stopped in 1981, 
although the journal was again published in 1988 under the Catalonian name of Treballs de Geografia; it, however, kept releasing papers related to its region. The journal was published for the last time in 1992, although its successor may be found in the Territoris journal published since 1998 by the Earth Sciences Department of the same university. In 1971, Cuadernos Geográficos de la Universidad de Granada was first published as an annex to the University Boletin and as a result of the creation of its Department of Geography. It is published once a year and it presents ordinary issues next to other extraordinary monographs. Its policy is to publish research papers related to society-land relations, as well as chronicles, notes and book reviews on geographical activity all over the world, and specifically from Spain and Andalucía, Latin-America and the Mediterranean countries. In 1974, the then University College of Castellón de la Plana began publishing Millars as a social sciences journal. In 1979 it split into several journals, and the geographic journal took the name of Millars : geografia $i$ història. Geographic articles were most of them about Physical Geography. In 1991 the name changed to Millars. Espai $i$ história.

11 In 1976, the first issue of Geocrítica. Cuadernos Críticos de Geografía Humana, was published by the Human Geography Department of the Universidad de Barcelona ; it was thought of as a renovative project by its director Horacio Capel. There is no doubt that it is one of the most unique and known journals that were started in this period. Until December 1994, 100 monographic issues were published with the express purpose to analyze the theoretical ideas that were prevailing in Geography, as a critical tool versus the social reality, and to develop "another" Geography, as a result of the collective creation and of a rigorous debate. In 1995, it was split in 4 digital journals to be mentioned below.

In 1977, another three new journals were started which followed very different paths. Thus, Didáctica Geográfica started as a joint publication of the Instituto de Ciencias de la Educación and the Geography Department of the Universidad de Murcia. After different ups and downs, nowadays it is the journal of the Asociación de Geógrafos Españoles (AGE)'s Didactics/Teaching Methods Group and the only journal specialized in this subject. Geographicalia was published in the Universidad de Zaragoza and it has had several break-ups in its life. Since 2000 its contents has diversified both spatially and in subjects, although it seems that Physical Geography is predominant. Lastly, the University College of Almería published Paralelo 37. Revista de Estudios Geográficos; it has undergone different stages and ups and downs until 1996 when its publishing was stopped. In 2003 the journal has started a new stage published by the Instituto de Estudios Almerienses and its contents is much diversified in subjects.

The last two years of the 1970s saw the appearance of new journals linked to the progressive consolidation of Geography Departments in other universities and to their professors wanting to have their own means to publish their own researches as well as those of other Spanish or even foreign researchers. In some cases, the journals are multidisciplinary, for instance in 1978 the Universidad de Málaga published Baetica. Estudios de Arte, Geografía e Historia. In these years, non-university institutions started other journals such as Lurralde, Investigación y Espacio ; it was first published in 1978 by the Instituto Geográfico Vasco Andrés de Urdaneta and it had a strong local character that has diversified in subjects and spatial reference along time.

The Revista Catalana de Geografía was started by the Sociedad Catalana de Geografía and published from 1978 to 1982. In 1985 the Instituto Cartográfico de Cataluña took over the journal and its contents became diversified. In 1994 the journal enlarged its subject and 
name into Terra. Revista Catalana de Geografía, Cartografía i Ciències de la Terra. Since 2007 it is only published in a digital format.

In all these journals, as a whole, until the 1980s and according to several studies made on them (Albet et al., 1992 ; Almoguera P. et al., 1984 ; García Ramón Mª D. et al., 1988 ; Gómez Mendoza J., 1997 ; del Rio I., 1975), the regional approach and articles related to Human Geography (especially Rural, Historical and Population Geography) were predominant. Geomorphology and Physical Geography were well represented until the mid-1950s. Theoretical and methodology articles are very few, although they will increase towards the end of the decade, a tendency that will go on later on. Cartographic and didactical subjects increased as specialized journals were published, as already pointed out. From the spatial point of view, articles on Spain were predominant, with a large number of articles on regional, county and local scales, which appeared in the newly-created journals and also in the traditional journals when they diversified their subjects.

\section{The consolidation}

Since 1980 new universities were created all over Spain and in most of them Geography departments were consolidated, which in the smaller universities were jointly created with other disciplines such as Art History, History, Urban Planning or Engineering. Most of these departments they start publishing their own journals with very different evolutions, as some journals have consolidated and are found among the most prestigious and widespread of Spanish geography, while others had had a very short life.

In 1980 there appeared three geographical journals. The Universidad de La Rioja published Cuadernos de Investigación Geográfica ; it appears once a year with articles that at the beginning were related to Physical and Human Geography and Regional Geographic Analysis and to Environmental Sciences, although it has little by little settled specially on Physical Geography. The Geography Department of the Universidad de Tarragona published Tarraco and, after several break-ups, stopped publishing it in 1995. More irregular has been the evolution of Norba, in the Universidad de Extremadura; it started as a joint journal of Art History, Geography and History, however as Geography increased its weight in the university the journal turned into a geography-only publication in 1985 . They want to make it into an internationally known journal, publishing the results of geographical researches as well as of other disciplines that follow an interdisciplinary analysis approach, and their objects are regional, physical and human subjects as well as any analytical techniques, both theoretical or practically. In spite of all their efforts, the journal is not published on a regular basis.

Much luckier was Ería which has also started in 1980 in the Universidad de Oviedo ; it has shifted from a yearly to a quarterly release while its contents has diversified towards theoretical and methodological subjects. It is open to geographers from many different origins and it has a large quality and dissemination.

In 1981 Anales de Geografía de la Universidad Complutense was started with the purpose to collect in its pages subjects related to the analysis and interpretation of geographical space and of regional, human and physical reality knowledge in Spain, paying a special attention to the urban space and regional environment of Madrid. It is relevant the presentation made in its first issue, where they pointed out the fact (the anomaly, perhaps) that, even though this university has one of the oldest geography departments, it still did not have its own 
journal, very likely because of the close relations that Geography professors and masters had with Estudios Geográficos and with the Revista General de la Universidad. It is said, however, that they always had a more or less latent desire -and need- of a specific speaker for geographic work, especially when since 1976 the Degree in Geography and two departments with a large number of professors had consolidated. It has to be pointed out that this journal was to deal specifically with concept and methodology problems, so little studied in other Spanish geographical journals at that time. Anales has had a regular evolution and it has become one of the most renowned and widespread Spanish journals. In 1982 the Universidad Autónoma de Barcelona published another journal on its own, which later on they published jointly with the University of Girona. Documents d'Anàlisi Geogràfica's precedents are three documentary series published by the Department since 1975 and which foretell the journal's main concerns: Documents d'Anàlisi Urbana, Documents d'Anàlisi Territorial y Documents d'Anàlisi Metodologic, since, as the journal already points out, it is addressed to researchers and professionals who question the interactions between nature, society, politics, economy and culture present in space at different scales, and to which Geography brings analysis and answers. Therefore, from the beginning, the journal covers very different subjects ranging from land planning to population, social and economic activities, physical environment, natural resources and, notably, contributions on Geography epistemology and methodology, with a clear leaning toward Anglo-Saxon Geography.

In the 1980s and 1990s the trend for each university to have their own geography journal kept going on. Thus, in 1983 the Instituto de Geografía of Universidad de Alicante published Investigaciones Geográficas; it appears very regularly and has increased its periodicity since 2002. In 1984 the Universidad de La Laguna started publishing the region-centered Revista de Geografía Canaria which was followed by Alisios. Revista de Geografía in 1991, of which only 3 issues were released. The Universidad Nacional de Educación a Distancia (the Spanish Open University) itself had a general journal called Espacio, Tiempo y Forma ; they started in 1988 a geographic series that was published until 2002, although it seems to have started a new life in 2008 having released only two issues till now.

Other journals are Cuadernos de Geografía de la Universidad de Cádiz (1989-1993) ; Polígonos published by the Geography Department of the Universidad de León from 1991 to 2000 and since 2002 by all the universities of the Castilla-Leon region; Serie Geográfica by the Universidad de Alcalá de Henares since 1991; Vegueta by the Universidad de las Palmas de Gran Canaria (1992-1998) ; Nimbus (since 1998) by the Universidad de Almería, with a title that shows its contents : a Climatology, Meteorology and Landscape journal; Xeográfica. Revista de Xeografía, territorio e medioambiente by the Universidad de Santiago de Compostela was started in 2001 with articles in the Galician language, and its last issue is from 2007.

To the university journals we can add those published by different academic institutions ; thus since 1984 the Sociedad Catalana de Geografía is publishing Treballs de la Societat Catalana de Geografía and its most recent issue is from 2010, or the Instituto de Estudios Ilerdenses is publishing Ilerda since 1990, specialized in Physical Geography.

However, the most relevant milestone of this period is the Boletín de la Asociación de Geógrafos Españoles (in 1984), published by this association founded in 1975 and the purpose of which, according to the journal, is to make possible disseminating the researches carried out by the Spanish geographers collective, and to become a discussion 
forum open to everyone who is interested in Geography. It is addressed to researchers, teachers, geography professionals and students from an open point of view, as well, to other social and natural disciplines. It allows integrating experiences, knowledge on research lines and work methodologies within Geography in its different special branches. It is a means to publish reflections on land, environmental and social-economic processes that directly deal with environment valuation and make easier to get to know reality, being thus able to overcome challenges appearing in the relations between social groups and land.

A review of the journals published during the $20^{\text {th }}$ century's two last decades, when many of them appear for first and last time, concludes as follows :

a. Spanish geographical research takes place basically in the university departments; therefore the creation of new Geography Departments results in a need to create new journals in which to publish local studies, some of which go beyond and become more widespread. We have to take into account that, at the gates of the $21^{\text {st }}$ century, Spanish geographers published more than $80 \%$ of their papers in Spanish journals (Canosa et al., 2004) basically. Just $15 \%$ of the articles were published in foreign journals, a percentage that will increase in later years.

b. From the thematic point of view, it must be pointed out that Human Geography branches increase their relevance as almost half of the published articles can be included in them, in spite of the existence of Physical Geography-specialized journals such as the Boletin Glaciológico Aragonés published since 2000 by the Geography and Land Planning Department of the Universidad de Zaragoza, as well as the growing interest for environmental questions. other momentum-gathering subjects are theory and methodology, and land planning. In recent years, we have to add a concern for new technologies applied to different fields, included Cartography.

c. Notwithstanding the growing number of foreign authors, almost $75 \%$ of the articles are about Spanish land in a sub-regional, county or local scale, which "once again shows that Spanish academic Geography still depends on the traditional link between Department location and land, object of the research" (Canosa et al., 2004), a fact that is also boosted because regional public funding is usually linked to the region being the research subject and, even, to the publishing in the region's language.

d. As pointed out by a report on results of geographic research drawn by AGE, one of the main weak points of Geography research is based in the proliferation of the journals where works are published and in their little diffusion, impact and recognition. It is also remarked that in many cases, journals are not published on a regular basis and continuously and that it is possible to find excessive inertias and a little presence or participation of researchers different from those related to the university publishing each journal. In the same report, they present the counterpoint of several geographic journals that started the external referee system more than ten years ago, the external referee system that many other journals have recently started in order to adapt themselves to the domestic and international criteria needed to be included in the most prestigious data bases.

e. Of the paper geographic journals already pointed out in the AGE's report, those that stand out because of the quality of their articles and their regular periodicity are the following, in alphabetical order :

Anales de Geografía (Universidad Complutense de Madrid)

Boletín de la Asociación de Geógrafos Españoles

Cuadernos de Geografía (Universidad de Valencia)

Documents d'Analisi Geográfica (Universidad Autónoma de Barcelona)

Ería (Universidad de Oviedo)

Estudios Geográficos (C.S.I.C. Madrid) 
Geocrítica (Universidad de Barcelona)

Geographicalia (Universidad de Zaragoza)

Investigaciones Geográficas (Universidad de Alicante)

To which we want to add, at least, Cuadernos de Geografía (Universidad de Granada).

\section{Recent changes}

geographic journals. First of all, very few new journals were published and released digitally following the way started in 1994 by Geocrítica. This journal stopped being published in paper and it gave birth to four digital publications: Scripta Vetera, the digitalized version of Geocrítica issues; Scripta Nova (Revista electrónica de Geografía y Ciencias Sociales), designed as an "international journal ... open to subjects, approaches and different methodologies" addressed basically to "the Spanish and Latin-American public"; although it is released with no regular basis, it has an average of 15 issues per year, all of them monographs, as its predecessor Geocrítica was. Other two electronic journals complement them : Biblio 3W (since 1996) and Ar@cne (since 1997). The former wants to review books that may be of interest for the Latin-American community, as well as other articles about the stage of the question of any subjects found to be interesting. The latter is about web pages and other Internet resources interesting for Geography. As a whole, these four journals are the most important Geography e-portal in Spain.

In 2001 Geofocus started its publishing only in a digital format, by AGE's Geographic Information Technologies Group. It is specialized in Geographic Information systems and their applications ; it is released once a year and has a good quality and dissemination.

Since 2007, Revista Catalana de Geografía, Cartografía y Ciencias de la Tierra is published only in digital format, as already pointed out.

The last journal to be integrated in the digital format is Geographos. It is published since 2010 in the Universidad de Alicante by the Grupo Interdisciplinario de Estudios Críticos y de América Latina (GIECRYAL) and it is designed for Geography and Social Sciences students. Its main purpose is "to encourage geographic and social research, discussion and comparison of ideas between students in the Universidad de Alicante and in other Spanish, European and Latin-American high education centers". On a yearly basis, it publishes articles drawn by Geography and Social Sciences students in Spanish, Catalonian, Galician and Portuguese, "openly going forth, since Geography is a Social and Human Science, for interdisciplinarity, criticism and knowledge transversality".

Most Spanish geographic journals are discussing whether they turn or not to the digital format, and in the Open Access platform of Spanish and Latin-American digital journals, apart from the above mentioned journals, there are only other seven names the contents of which, although they are published in paper, can be found in Internet: Anales de Geografía de la Universidad Complutense, Boletín de la AGE, Didáctica Geográfica, Documents d'Anàlisi Geogràfica, Estudios Geográficos, Investigaciones Geográficas and Papeles de Geografía. The process is going on and their number is growing because when journals go through economic problems to publish in paper, it is likely they opt for this format. Besides, we have to take into account that having a journal in Internet does not imply a high economic cost, while its national and international dissemination is very much enlarged. Portals such as DIALNET (Universidad de La Rioja) or e revistas, of the CSIC, harbor a large 
number of Spanish geographic journals although not always it is possible to view the whole articles, especially when they are in older issues.

\section{The evaluation of Spanish geographic journals}

\section{international quality criteria and periodicity parameters in order to increase their} valuation and presence in data bases with the highest impact indexes. However, Spanish journals run into different problems when trying to get included in the most prestigious English-speaking indexes, basically the language, because although some articles in English had been published in some journals, most articles are in Spanish and in other Spanish State languages. To this we have to add the local scale of the articles, which are not theoretical case studies as is the usual in English-speaking journals. Finally, we have to point out also that many Spanish geographic journals do not meet the criteria on periodicity, organization and evaluation required by those data bases.

In one of the most complete works on Spanish journals evaluation (Olcina and Román 2004), authors pointed out the failure of the SSCI and its best known indicators, such as the impact and immediacy indexes, to show geographic work in Spanish journals because of the little or none presence of these journals in the data base. Only Scripta Nova and, since 2005, the Boletín de la Asociación de Geógrafos Españoles appeared in SSCI with a very low impact index at least until 2009. Afterwards, those journals were not quoted in this index and no other Spanish journal has appeared even though their total number has increased and their publishing and scientific quality has improved.

In other prestigious international data bases, specifically in those with quality requirements, very few Spanish geographical journals are entered although they meet the same or even more criteria than other journals already included; therefore, we have to take into account the questions of language and subject, once again. Thus in Scopus, generated by the Dutch publishing house Elsevier, there are only 5 journals (Table I). In other USA data bases such as HLAS (the Hispanic catalogue of the Congress Library), Geobase, GeoRef, Population Index or Econlit; in the British Ulrich, PIO, Urbadoc, Cambridge ; in the Swedish DOAJ ; in the French FRANCIS or in the UNESCO-sponsored ISD, there is only a short number of Spanish geographical journals. And, apart from the Latindex, their presence is little even in Spanish-speaking data bases such as the ALyC network, where they are only 3 . Of the 27 journals of the Latindex set, just 15 appear in Spanish databases, which limits their international dissemination.

That's why Olcina and Román highlight other data bases focused on journals published in Spain or Latin-America, and have made a list of quality criteria ranging from international publishing rules, article reviewing system, percentage of authors external to the publisher (which in relation to the initial object of many Spanish journals, as already pointed out, is a truly booster) and value of international contributions, systematic presence in prestigious international data bases, number of volumes per year and periodicity, and so on, up to the 33 criteria for Latindex ( 36 criteria for digital format journals), of which any journal has to meet at least 25 to be included in its prestigious catalogue (the result of the cooperation of 15 Latin-American countries, plus Spain and Portugal). Apart from this data base, Olcina and Román analyze the evaluation given in a 2002 enquiry by university professors and CSIC researchers. They had to value geography journals as : Very relevant for the discipline (A), important (B), of a general interest (C) or

Belgeo, 1-2 | 2012 
of a marginal interest (D). Their answers were used to make other evaluation indexes that enabled setting another ranking complementary to the Latindex. Other valuation attempts, such as the one by the above authors or those by the Universidad de Granada or by the CSIC's DICE and RESH data bases, are taken into account by the boards that assess research by Spanish professors. The prestige and the positive evaluation that for an academic career implies publishing in a journal well-thought of in many data bases have resulted in journal publishers wanting to improve their meeting quality parameters. For instance, Anales de Geografía de la UCM or Ería met 25 of the Latindex criteria in 2002 and nowadays they are meeting all the 33.

In Latindex ${ }^{1}$, in December 2011, 27 Spanish geographic journals appeared, with information on how many criteria they meet, the data bases they are included, and if there is an e-link to, at least, tables of contents and abstracts (Table I). Of these journals, of those in paper, 6 meet the 33 quality criteria (Anales, Boletin de la AGE, Cuadernos Geográficos, Estudios Geográficos, Investigaciones Geográficas and Papeles de Geografía) while 10 other journals meet 30 or more criteria. Of the digital-format journals, Geofocus meets most criteria, while all the others meet more than 30 criteria.

Analyzing journal evaluation by professors and researchers in 2002 and the indexes prepared by Olcina and Román, it is found that, in general, they highlight the journals that best meet Latindex criteria, although it is pointed out that the evaluation may be affected by the journal's age (subject to the journal been related to an university Geography Department, as Estudios Geográficos for instance, while that of the Boletín de la Real Sociedad Geográfica has been occasionally valued until recently), its periodicity, distribution, higher or lower internet access, etc.

In their interesting evaluation model, the above authors have taken into account both publishing quality criteria and the journal valuation by professors, journal diffusion, its inclusion in internationally prestigious data bases, periodicity and external referees. We agree with these authors that publishing quality criteria average is high and tending to be increased in Spanish geographic journals, since in 2002 Olcina and Román found 21 geographic journals in Latindex, in 2011 they are 27. The journals better valuated by the Spanish geographic scientific community are the Boletín de la AGE, Estudios Geográficos, Anales de Geografía de la UCM, Scripta Nova, Documents d'Anàlisi Geogràfica and Ería, to which if we combine publishing quality and valuation, we can add Geographicalia, Investigaciones Geográficas, Cuadernos de Geografía, Cuadernos Geográficos de la Universidad de Granada, Papeles de Geografía and Cuadernos de Investigaciones Geográficas de La Rioja.

An important journal evaluation component is their impact index. In the case of any Spanish journal, the most widespread index is the IN-RECS (Social Sciences Spanish Journals impact index), which is prepared by counting author book quotations and enables knowing the true dissemination of published articles. After consulting this index, it is clear that once again the same journals are on top with more or less yearly variations. However, an interesting element is the low number of international quotations of Spanish journals and even the low number of national quotations, maybe because of the already pointed out local character.

Similar characteristics can be found in the RESH and DICE evaluation. In the latter, we have to point out the low values of the Spanish journals dissemination index in relation to the higher or lower selection data bases in which they are included, as well as their thematic specialization, with a maximum value of 16 points, and that only 10 journals get more than 8 points. This indicator is improving because publishers are getting more 
concerned in meeting criteria set by the most prestigious data bases. With respect to two relevant criteria, international contribution and external authors, they are low in most journals. In the case of RESH, it is to be pointed out that the Geography professors and researchers valuation index has a similar ranking to the above, with similar total scores.

\section{Some first conclusions}

Spanish Geography publishes a good number of journals and most of them meet most of the international publishing quality criteria and, therefore, they are able to disseminate the growing scientific production of the also growing collective of geographers of all the Spanish research centers and universities. However, this high number is its strength and one of its weak points.

In fact, many journals had been personal projects that have not found the support of the department or university, which has affected its continuity and even its quality. As pointed out by Olcina and Román, not all the geographers are ready to get involved in the different tasks, including a careful assessment of articles in a short period of time, that result in publishing a journal with the proper periodicity and quality. There is the need to improve many of these procedures by promoting exchanges through Internet. The increase in the number of journals has also increased these tasks that not always are duly recognized or valued by academic professors.

One of the weak points of many journals is its dissemination. We have to take into account that only two journals are included in the SSCI, which lessens the international evaluation and consideration of the other journals. It is true that the language and the local character of many of our journals can be a handicap, but it cannot be the only one because, as Gutiérrez Puebla (1999) pointed out, many of the journals appearing in said index have a similar bias and a relative internationalization of their authors, although most of the journals are Anglo-Saxon or written in English. It makes possible thinking that data bases evaluation and their rankings are subjective, although it does not mean that quality and dissemination of the journal cannot be improved, by including it in the largest number of data bases.

The subject matter of our journals is another question already studied in part by Albet, García Ramón and Nogué in 1992 and recently in the report on Geography research published in Geografía 21 (Gil Olcina et al., 2001). Later on, using the CSIC data bases, Olcina and Román have gone through their evolution from 1985 to 2002, reaching the conclusion that the prevailing topics are the classical ones in Physical Geography, Population Geography, Rural Geography, Urban Geography, Economic Geography and Political Geography, but with a strong regional approach. Of these subjects, the ones that are losing relevance are rural topics, in keeping with the Spanish urban development and with the stronger interest for demographic, economic and political aspects. Articles on theoretical and methodological subjects are increasing, though not those on pure theory, but those on research techniques and methods, with a preference for cartography, remote-sensing and GIS.

43 Among the novelties, we have to point out articles on tourism and leisure, local development, land planning, environment, sustainability, culture, globalization, innovation, gender and other similar topics. As a whole, in the last years there is a tendency to give more relevance to new approaches and theoretical and methodological 
trends, most of them of an Anglo-Saxon origin, which may help to generate a larger impact of Spanish geographic journals. However, we can also agree that their number must be reduced, at least for the journals in paper, not only due to economic reasons, but also to focus the efforts in increasing the publishing quality and the visibility of the most renowned journals, whatever they may be.

In this sense, one of the most immediate challenges is digital publishing. The idea is to be present in the network not only with periodicals published exclusively in this format, but also with the complete articles of the journals published in paper and not just their abstracts and tables of contents. The journals that are doing this have increased significantly their visibility.

The future of the Spanish geographic journals, in any case, lies on journals meeting their periodicity while keeping their quality, on increasing their internationalization, both with regards to authors and referees, and to topics, on globally and epistemologically putting on context local problems so they can be understood at a lower scale and be compared with other international case studies, and on increasing, finally, an international visibility in relation to the well-known quality and present dynamism of Spanish Geography. Obviously, the concentration of different magazines could heavily help to improve all these conclusions.

Table 1. Spanish geographical journals included in the Latindex Catalogue in 2011.

\begin{tabular}{|c|c|c|c|c|c|c|}
\hline JOURNAL & PUBLISHER & $\begin{array}{l}\text { STARTING } \\
\text { YEAR }\end{array}$ & $\begin{array}{l}\text { DATA } \\
\text { BASES } \\
\text { (number of } \\
\text { criteria) }\end{array}$ & $\begin{array}{l}\text { PROFESSORS } \\
\text { VALORATION }\end{array}$ & $\begin{array}{l}\text { ELECTRONIC } \\
\text { LINK }\end{array}$ & $\begin{array}{l}\text { TOTAL } \\
\text { RESH } \\
\text { SCORE }\end{array}$ \\
\hline $\begin{array}{l}\text { Anales de } \\
\text { Geografía de la } \\
\text { UCM }\end{array}$ & $\begin{array}{l}\text { Universidad } \\
\text { Complutense. } \\
\text { Madrid }\end{array}$ & 1981 & $\begin{array}{l}\text {-Latindex } \\
(33) \\
\text {-ISOC } \\
\text {-FRANCIS } \\
\text { Ulrich } \\
\text { ISDS } \\
\text { Cambridge } \\
\text { Scientific } \\
\text { Abstracts }\end{array}$ & 85.48 & Yes & 89.68 \\
\hline Ar@cne & $\begin{array}{l}\text { Univ. } \\
\text { Barcelona }\end{array}$ & 1997 & $\begin{array}{l}\text { Latindex } \\
(31)\end{array}$ & $\mathrm{NC}$ & Only digital & -- \\
\hline Biblio 3W & $\begin{array}{l}\text { Univ. } \\
\text { Barcelona }\end{array}$ & 1996 & $\begin{array}{l}\text { Latindex } \\
(34)\end{array}$ & $\mathrm{NC}$ & Only digital & -- \\
\hline Boletín AGE & AGE. Madrid & 1984 & $\begin{array}{l}\text { Latindex } \\
(33) \\
\text { ISOC } \\
\text { Scopus, } \\
\text { SSCI } \\
\text { URBADOC }\end{array}$ & 88.57 & Yes & 89.17 \\
\hline
\end{tabular}




\begin{tabular}{|c|c|c|c|c|c|c|}
\hline Boletín R.S.G. & $\begin{array}{l}\text { R.S.G. } \\
\text { Madrid }\end{array}$ & 1876 & $\begin{array}{l}\text { Latindex } \\
(30) \\
\text { ISOC }\end{array}$ & 46.17 & Yes & 57.89 \\
\hline $\begin{array}{l}\text { Cuadernos de } \\
\text { Geografía }\end{array}$ & $\begin{array}{l}\text { Univ. } \\
\text { Valencia }\end{array}$ & 1964 & $\begin{array}{l}\text { Latindex } \\
(31) \\
\text { ISOC }\end{array}$ & 55.57 & Yes & 60.12 \\
\hline $\begin{array}{l}\text { Cuadernos de } \\
\text { Investigación } \\
\text { Geográficas }\end{array}$ & Univ. La Rioja & 1980 & $\begin{array}{l}\text { Latindex } \\
(32) \\
\text { FRANCIS } \\
\text { ISOC } \\
\text { ICYT }\end{array}$ & 16.28 & Yes & 77.74 \\
\hline $\begin{array}{l}\text { Cuadernos } \\
\text { Geográficos }\end{array}$ & $\begin{array}{l}\text { Univ. } \\
\text { Granada }\end{array}$ & 1971 & $\begin{array}{l}\text { Latindex } \\
(33) \\
\text { ISOC } \\
\text { DOAJ } \\
\text { Red AL y C }\end{array}$ & 39.13 & Yes & 83.28 \\
\hline $\begin{array}{l}\text { Didáctica } \\
\text { Geográfica }\end{array}$ & $\begin{array}{l}\text { Fac. } \\
\text { Educación } \\
\text { Madrid }\end{array}$ & 1977 & $\begin{array}{l}\text { Latindex } \\
(32)\end{array}$ & $\mathrm{NC}$ & Yes & -- \\
\hline $\begin{array}{l}\text { Documents } \\
\text { d'Anàlisi } \\
\text { Geogràfica }\end{array}$ & $\begin{array}{l}\text { Univ. } \\
\text { Autónoma } \\
\text { Barcelona }\end{array}$ & 1982 & $\begin{array}{l}\text { Latindex } \\
(32) \\
\text { Geobase } \\
\text { Scopus } \\
\text { ISOC } \\
\text { FRANCIS } \\
\text { GEODOC }\end{array}$ & 75.92 & Yes & 77.65 \\
\hline Ería & Univ. Oviedo & 1980 & $\begin{array}{l}\text { Latindex } \\
(30) \\
\text { ISOC } \\
\text { DIALNET }\end{array}$ & 73.97 & Yes & 80.84 \\
\hline $\begin{array}{l}\text { Estudios } \\
\text { Geográficos }\end{array}$ & C.S.I.C. & 1940 & \begin{tabular}{|l} 
Latindex \\
$(33)$ \\
ISOC \\
ICYT \\
Scopus \\
America, \\
history and \\
life \\
FRANCIS \\
GEOBASE \\
GEOREF \\
Historical \\
Abstracts
\end{tabular} & 85.56 & Yes & 95.69 \\
\hline
\end{tabular}




\begin{tabular}{|c|c|c|c|c|c|c|}
\hline Geofocus & AGE & 2001 & $\begin{array}{l}\text { Latindex } \\
(35) \\
\text { ISOC } \\
\text { DOAJ }\end{array}$ & 19.27 & Only digital & -- \\
\hline Geographicalia & $\begin{array}{l}\text { Univ. } \\
\text { Zaragoza }\end{array}$ & 1977 & $\begin{array}{l}\text { Latindex } \\
(31) \\
\text { GeoRef } \\
\text { PASCAL } \\
\text { Population } \\
\text { Index } \\
\text { ISOC }\end{array}$ & 56.76 & Yes & 77.08 \\
\hline $\begin{array}{l}\text { Investigaciones } \\
\text { Geográficas }\end{array}$ & $\begin{array}{l}\text { Univ. } \\
\text { Alicante }\end{array}$ & 1983 & $\begin{array}{l}\text { Latindex } \\
(33) \\
\text { DOAJ } \\
\text { ISOC } \\
\text { GEOBASE } \\
\text { Red ALyC }\end{array}$ & 61.06 & Yes & 82.01 \\
\hline Lurralde & $\begin{array}{l} \\
\text { Inst. } \\
\text { Geográfico } \\
\text { Vasco }\end{array}$ & 1978 & $\begin{array}{l}\text { Latindex } \\
(27) \\
\text { Geobase } \\
\text { ICYT, } \\
\text { ISOC } \\
\text { FRANCIS } \\
\text { Scopus } \\
\text { Zoological } \\
\text { Record }\end{array}$ & 18.51 & $\begin{array}{l}\text { Digital } \\
\text { Version } \\
\text { since } 2002\end{array}$ & 59.95 \\
\hline Millars & $\begin{array}{l}\text { Univ. } \\
\text { Castellón }\end{array}$ & 1974 & $\begin{array}{l}\text { Latindex } \\
(29) \\
\text { ISOC }\end{array}$ & $\mathrm{NC}$ & & 41.50 \\
\hline Minius & Univ. Vigo & 1992 & $\begin{array}{l}\text { Latindex } \\
(30) \\
\text { DIALNET } \\
\text { ISOC }\end{array}$ & $\mathrm{NC}$ & Yes & -- \\
\hline Nimbus & Univ. Almeria & 1998 & $\begin{array}{l}\text { Latindex } \\
(31) \\
\text { ISOC }\end{array}$ & 15.55 & & 39.22 \\
\hline $\begin{array}{l}\text { Papeles de } \\
\text { Geografía }\end{array}$ & Univ. Murcia & 1968 & $\begin{array}{l}\text { Latindex } \\
(33) \\
\text { ISOC } \\
\text { Red ALyC } \\
\text { DOAJ, } \\
\text { HLAS }\end{array}$ & 41.66 & Yes & 73.67 \\
\hline
\end{tabular}




\begin{tabular}{|c|c|c|c|c|c|c|}
\hline Polígonos & Univ. León & 1991 & $\begin{array}{l}\text { Latindex } \\
(31) \\
\text { ISOC } \\
\text { GEODADOS }\end{array}$ & 15.7 & Yes & 48.57 \\
\hline Scripta Nova & $\begin{array}{l}\text { Univ. } \\
\text { Barcelona }\end{array}$ & 1997 & $\begin{array}{l}\text { Latindex } \\
(34) \\
\text { SSCI } \\
\text { Scopus } \\
\text { ISOC }\end{array}$ & 45.0 & Only digital & 83.09 \\
\hline $\begin{array}{l}\text { Serie } \\
\text { Geográfica }\end{array}$ & $\begin{array}{l}\text { Univ. Alcalá } \\
\text { de Henares }\end{array}$ & 1991 & $\begin{array}{l}\text { Latindex } \\
(31) \\
\text { ISOC }\end{array}$ & 19.16 & & 59.00 \\
\hline Territoris & $\begin{array}{l}\text { Univ. Islas } \\
\text { Baleares }\end{array}$ & 1998 & \begin{tabular}{|l} 
Latindex \\
$(29)$ \\
ISOC \\
ICYT \\
DIALNET
\end{tabular} & 11.28 & Yes & -- \\
\hline Treballs & $\begin{array}{l}\text { Societat } \\
\text { Catalana de } \\
\text { Geografía }\end{array}$ & 1984 & $\begin{array}{l}\text { Latindex } \\
(28) \\
\text { ISOC }\end{array}$ & 15.33 & Yes & 34.38 \\
\hline Vegueta & $\begin{array}{l}\text { Univ. Las } \\
\text { Palmas }\end{array}$ & 1992 & $\begin{array}{l}\text { Latindex } \\
(28) \\
\text { ISOC }\end{array}$ & $\mathrm{NC}$ & Yes & |-- \\
\hline Xeográfica & $\begin{array}{l}\text { Univ. } \\
\text { Santiago de } \\
\text { Compostela }\end{array}$ & 2001 & $\begin{array}{l}\text { Latindex } \\
(32) \\
\text { ISOC }\end{array}$ & 5.15 & & -- \\
\hline
\end{tabular}

OWN MAKINg FROM DIFFERENT DATA BASES AND INDEXES.

\section{BIBLIOGRAPHY}

ALBET A., GARCÍA RAMON M.D. \& NOGUÉ J. (1992), “Cincuenta años de geografía en España : una aproximación a partir de las revistasuniversitarias de Geografía", in La Geografía en España (1970-1990) (Aportación Española al XXVII Congreso de la Unión Geográfica Internacional, Washington, 1992), Real Sociedad Geográfica y Asociación de Geógrafos Españoles, Fundación BBV, Madrid, pp. 49-57.

ALMOGUERA P. et al. (1984), “La evolución de la Geografía española 1940-1979”, in III Coloquio Ibérico de Geografía, Barcelona. 
BOSQUE MAUREL J., CABO ALONSO A. et al. (1992), “Instituciones y asociaciones geográficas”, in BOSQUE MAUREL J. et al., La Geografía en España (1970-1990), Madrid, RSG, AGE y F. BBV, pp. 35-47.

BOSQUE MAUREL J. (2004), “La Real Sociedad Geográfica. 125 años de existencia”, in COMITÉ ESPAÑOL DE LA UNIÓN GEOGRÁFICA INTERNACIONAL, La Geografía española ante los retos de la sociedad actual, Aportación Española al XXX Congreso de la Unión Geográfica Internacional (edición bilingüe español e inglés), Glasgow 2004, Madrid, RSG, AGE, Iberdrola y Fundación Santander Central Hispano, 791 págs.

BOSQUE MAUREL J. (1984), “Los estudios de Historia de la Geografía en España”, Madrid, Anales de Geografía de la Universidad Complutense, 4, pp. 231-245.

BOSQUE MAUREL J. (1987), "Estructura académica interna de la geografía actual en España”, Barcelona, Treballs de la Societat Catalana de Geografía, 12, pp. 27-54.

BOSQUE MAUREL J. (1990), “La geografía española entre 1900 y 1936. El peso de la geografía no universitaria”, Estudios Geográficos, Homenaje a Julia López Gómez, Madrid, LI, pp. 273-291.

CANOSA ZAMORA E. et al. (2004), Los Departamentos Universitarios de geografía y su producción científica", Informe AGE.

GARCÍA RAMÓN Ma D. et al. (1988), "La receptividad a influencias extranjeras en revistas españolas de geografía : un análisis bibliométrico”, Anales de Geografía de la Universidad Complutense, 8, pp. 11-24

GIL OLCINA A., GÓMEZ MENDOZA J., LÓPEZ ONTIVEROS A., MATEU BELLÉS J., MORALES MATOS G. \& ZOIDO NARANJO F. (2001), "Informe sobre resultados cualitativos de la investigación en Geografía”, Geografía 21, Asociación de Geógrafos Españoles, Madrid, pp. 115-135.

GÓMEZ MENDOZA J. (1997), “La formación de la escuela española de Geografía (1940-1952) : instituciones, revistas, congresos y programas”, Ería, 42, pp. 107-146.

GUTIÉRREZ PUEBLA J. (1999), “Las revistas internacionales de Geografía : internacionalización e impacto", Boletín de la AGE, 27, pp. 117-134

LÓPEZ ONTIVEROS A. (1995-96), "Evolución reciente de la investigación geogràfica española”, Boletín de la Asociación de Geógrafos Españoles, 21-22 (special issue with a new title La nueva realidad geográfica en España. Aportación de la Asociación de Geógrafos Españoles al $28^{\circ}$ Congreso Internacional de Geografía, La Haya, 1996), Madrid, pp. 119-132.

del RIO I. (1975), “La Geografía en España desde 1940 a 1972, a partir de sus principales revistas geográficas", Estudios Geográficos, 36, 140-141, pp. 1033-1048.

OLCINA J. \& ROMAN A. (2004), Las revistes españolas de Geografía : cambios y adaptación a los criterios editoriales de calidad.

SÁNCHEZ NISTAL J.M‥ (1995), “La geografía española a través de sus revistas : una aproximación bibliométrica”, Estudios Geográficos, 56, 229, pp. 547-621.

VALENZUELA RUBIO M. (2000), “La diversidad en la bibliografía geográfica sobre España - una aproximación al período 1990-2000, Vivir la diversidad en España, Aportación Española al XXIX ${ }^{\circ}$ Congreso de la Unión Geográfica Internacional. Asociación de Geógrafos Españoles, Real Sociedad Geográfica y Caja Duero, Madrid, pp. 357-372. 


\section{NOTES}

1. The Latindex system results from the cooperation of 15 countries of Latin America, Spain and Portugal. Its main purpose is to improve the quality and promote the international dissemination of the scientific journals published in the Ibero-American area. More information can be found in The Latindex system results from the cooperation of 15 countries of Latin America, Spain and Portugal. Its main purpose is to improve the quality and promote the international dissemination of the scientific journals published in the Ibero-American area. More information can be found in www.latindex.org

\section{ABSTRACTS}

This article reviews the short and diversified history of the Spanish Geographical journals, within the framework of the general Spanish geographic tradition. During the second half of the 20th Century, a fragmentation of the university Geography groups took place with a multiplication of journals. This fragmentation appears as a big difficulty to reinforce and internationally disseminate the main results of Spanish geographical research. Through the most popular journals database it is possible to evaluate the impact of these Spanish journals, which is always very little. Some conclusions related to language and content problems are advanced in order to improve the knowledge of the great and diversified Spanish geography all around the world.

Cet article analyse l'évolution brève et diversifiée des revues de géographie espagnoles, dans le contexte général de la tradition géographique. À partir de la deuxième moitié du XXème siècle il y eu une fragmentation des groupes de géographes universitaires ce qui a produit une multiplication des revues. Cette fragmentation devient la difficulté majeure pour l'internationalisation et la diffusion des principaux résultats de la recherche géographique espagnole. À travers des bases de données de revues les plus connues on a pu évaluer l'impact des revues espagnoles, qui est toujours très réduit. On avance finalement quelques conclusions relatives aux problèmes de la langue et des contenus de la majorité des articles des revues espagnoles comme explication de la méconnaissance de l'importance et de la diversité de la géographie espagnole dans le monde actuel.

\section{INDEX}

Mots-clés: géographie espagnole, revues géographiques espagnoles, impact international, fragmentation, langue

Keywords: Spanish Geography, Spanish geographical magazines, international impact, fragmentation, language 


\section{AUTHORS}

\section{AURORA GARCIA BALLESTEROS}

Universidad complutense de Madrid, auroragb@telefonica.net

\section{CARLES CARRERAS I VERDAGUER}

Universitat de Barcelona, carlescarreras@yahoo.com 